\title{
Health-related quality of life in Indonesian type 2 diabetes mellitus outpatients measured with the Bahasa version of EQ-5D
}

\author{
Bustanul Arifin ${ }^{1,2,3}$ - Lusiana Rusdi Idrus ${ }^{1,3,7}$. Antoinette D. I. van Asselt ${ }^{1,3,5} \cdot$ Fredrick Dermawan Purba $^{8,9}$. \\ Dyah Aryani Perwitasari $^{10}$. Jarir At Thobari ${ }^{6}$. Qi Cao ${ }^{1}$. Paul F. M. Krabbe Maarten J. Postma $^{1,3,4,5,11,12}$
}

Accepted: 9 January 2019 / Published online: 16 January 2019

(c) The Author(s) 2019

\begin{abstract}
Objectives To present EuroQol-5D (EQ-5D) index scores in Indonesian type 2 diabetes mellitus (T2DM) outpatients and to investigate the associations between EQ-5D and socio-demographic characteristics and clinical condition.

Methods Socio-demographic data were collected by interviewing participants, clinical data were obtained from treating physicians and self-reporting. Participants originated from primary and secondary care facilities in the Java and Sulawesi regions. Ordinal regression analysis was conducted with the quintiles of the EQ-5D index scores as the dependent variable to investigate the multivariate association with the participants' socio-demographic characteristics and clinical condition.

Results 907 participants completed the five-level Indonesian version of the EQ-5D. The mean age of the participants was 59.3 (SD 9.7), and 57\% were female. The overall EQ-5D index score was 0.77 (0.75-0.79). Male participants had a higher EQ-5D index score compared to females, and the highest percentage of self-reported health problems was in the pain/ discomfort dimension (61\%). Factors identified as being significantly associated with lower EQ-5D index scores were: (i) treatment in secondary care, (ii) lower educational level, (iii) dependency on caregivers, (iv) not undergoing T2DM therapy, and (v) being a housewife.

Conclusion This study provides estimates of EQ-5D index scores that can be used in health economic evaluations. As housewives were found to experience more T2DM-related pain/discomfort and anxiety/depression, targeted approaches to reduce these problems should be aimed specifically at this group of patients. Potential approaches could involve diseasespecific-counselors (health literacy partners) who provide routine monitoring of T2DM therapy as well as improved health promotion among T2DM communities.
\end{abstract}

Keywords EQ-5D-5L $\cdot$ Index scores $\cdot$ Type 2 diabetes mellitus $\cdot$ Health-related quality of life $\cdot$ Indonesia

Bustanul Arifin

bustanul.arifin.ury@gmail.com;

ury.bustanul.arifin@gmail.com; b.arifin@rug.nl

1 Unit of Pharmacotherapy, Epidemiology \& Economics (PTE2), Department of Pharmacy, Faculty of Science and Engineering (FSE), University of Groningen, Groningen, The Netherlands

2 Banggai Laut Public Hospital, Banggai Laut Local Government, Central Sulawesi, Indonesia

3 Institute of Science in Healthy Ageing \& healthcaRE (SHARE), University Medical Center Groningen (UMCG), University of Groningen, Groningen, The Netherlands

4 Department of Health Sciences, University of Groningen, University Medical Center Groningen, Groningen, The Netherlands

5 Department of Epidemiology, University of Groningen, University Medical Center Groningen, Groningen, The Netherlands
6 Department of Pharmacology and Therapy, Faculty of Medicine, Public Health and Nursing, Universitas Gadjah Mada, Yogyakarta, Indonesia

7 Bekasi General Hospital, West Java Local Government, Bekasi, Indonesia

8 Department of Psychiatry, Medical Psychology and Psychotherapy Section, Erasmus MC University Medical Center, Rotterdam, The Netherlands

9 Department of Developmental Psychology, Faculty of Psychology, Padjadjaran University, Jatinangor, Indonesia

10 Faculty of Pharmacy, Ahmad Dahlan University, Yogyakarta, Indonesia

11 Departement of Economics, Econometrics \& Finance, Faculty of Economics \& Business, University of Groningen, Groningen, Netherlands

12 Department of Pharmacology and Therapy, Faculty of Medicine, Universitas Airlangga, Surabaya, Indonesia 


\section{Introduction}

The World Health Organization (WHO) has estimated that type 2 diabetes mellitus (T2DM) will be the seventh leading cause of death in 2030 [1]. Furthermore, the U.S. Centers for Disease Control and Prevention (CDC) estimated that mortality in T2DM patients is twice as high as in people of similar age without T2DM [2]. In Indonesia, the number of T2DM patients has increased rapidly, not only in urban but also in rural areas [3], which makes Indonesia one of the countries with the most T2DM cases in the world [4]. In 2011, the International Diabetes Federation (IDF) reported that there were 7.3 million T2DM patients living in Indonesia [5] and this number had increased to 10.3 million in 2017 [4]. The Ministry of Health of the Republic of Indonesia reported, based on the comparison of T2DM data in 2007 and 2013, that new T2DM cases had doubled from 1.1 to $2.1 \%$ [3]. Recently, new cases were found in the younger age groups (15-24 years) and relatively more females than males were living with T2DM. As for the level of education, the highest percentage of T2DM was found in those who never attended school at $10.4 \%$ compared to those with a university degree at $5.9 \%$ [3]. With regard to clinical condition, $60 \%$ of T2DM patients in Indonesia have at least one T2DM-related complication, with kidney neuropathy and retinopathy being the most common complications $[6,7]$.

T2DM is a serious and complex chronic disease which significantly affects the daily lives of the patients, their families, and the general population in terms of premature mortality, healthcare expenditures, and lower healthrelated quality of life (HRQoL) [4]. Early treatment has been shown to be effective in lowering the aforementioned burdens as well as T2DM-related complications [8]. Endstage T2DM-related complications are related to higher healthcare expenditures and lower HRQoL compared to those without complications [4]. Well-structured management strategies for T2DM are warranted and interpretation and evaluation of HRQoL can help to evaluate such strategies. As the portfolio of strategies is broad and may comprise various target groups (those with advanced T2DM, those with comorbidities, those with a high dependency on a caregiver, etc.), detailed estimation for subgroups is, therefore, needed.

To our knowledge, no studies have been done to measure generic HRQoL values such as the EuroQoL-5D (EQ-5D) index scores in T2DM outpatients in Indonesia. Therefore, the aim of this study was to present generic EQ-5D index scores based on socio-demographic characteristics and clinical condition and to subsequently investigate the multivariate association between those variables. Since only the 5-level version (EQ-5D-5L) has a value set based on the Indonesian general population [9], we specifically used the EQ-5D-5L instrument in this study. We focused on two major regions in Indonesia, namely Java and Sulawesi. Java is the island where the majority of Indonesia's population (57\%) resides and can be considered representative for the western part of Indonesia [10]. Sulawesi has the highest incidence of T2DM in the whole country [3] and can represent the central and eastern part of the country.

\section{Methods}

\section{Study design and setting}

A cross-sectional study was carried out in Java and Sulawesi from November 2015 to October 2017 in T2DM outpatients in primary and secondary care settings. This study was approved by the Medical Ethics Committee of Universitas Gadjah Mada in Yogyakarta (KE/FK/1188/EC, 12 November 2014, amended 16 March 2015), and the Ethics Committee of Ahmad Dahlan University in Yogyakarta (011703028, 4 April 2017).

\section{Java region}

In the primary care setting, surveys and data collection were conducted in three family doctor clinics in Yogyakarta and a T2DM outpatient community in Surakarta (Central Java). In the secondary care setting, RSUD Dr Moewardi Hospital in Surakarta and Rumah Sehat Terpadu Dompet Dhuafa Hospital in Bogor (West Java) were chosen as the study sites.

\section{Sulawesi region}

Data collection was carried out at the Amirah clinic in Luwuk, Banggai (Central Sulawesi) as the study site for the primary care setting. We selected RS Akademis Jaury Hospital in Makassar (South Sulawesi) as our secondary care site.

\section{Participants}

Patients were included in the study if they were diagnosed with T2DM by a consulting resident of internal medicine, had a minimum age of 18 years, and were willing to sign the informed consent form. For participants who were illiterate or had other difficulties with reading the form, the consent was given by the caregiver who would also further assist the participant during the subsequent data collection process. 


\section{Instrument}

The EQ-5D-5L is a generic HRQoL instrument. The paper and pencil version used in this study consists of two pages [11]. The first page is the EQ-5D classification consisting of a descriptive system that comprises five dimensions: mobility, self-care, usual activities, pain/discomfort, and anxiety/ depression. Each dimension has five levels: no problems, slight problems, moderate problems, severe problems, and unable/extreme problems which represent the severity of problems for the specific dimension. A single digit expresses the level selected for that specific dimension. Therefore, the five-digit number for five dimensions describes a specific health state. For example, '11111' indicates 'no problems in any of the five dimensions,' while '21134' indicates slight problems in the mobility dimension, no problems in the selfcare and usual activities dimensions, moderate problems in the pain/discomfort dimension, and severe problems in the anxiety/depression dimension. Each EQ-5D health state is then calculated to a single index score based on the preference of the relevant general population; i.e., the Indonesian value set in this case $[9,12]$. For instance, the health state of ' 11111 ' corresponds to the maximum EQ-5D index score of 1.00, and '21134' leads to a score of 0.56 . The second page of the instrument comprises the visual analogue scale, labelled EQ-VAS. This thermometer-like scale (ranging from 0 to 100) reflects the patient's health in general, representing a more integral measure than the EQ-5D index scores [12]. In addition, the EQ-VAS represents the patient perspective, whereas the EQ-5D index score, since it uses population preferences, reflects the societal perspective. The participants were asked to rate their own health, where zero indicates the worst imaginable health state, and 100 indicates the best imaginable health state.

\section{Data collection procedure and data sources}

To ensure a smooth process of distributing the EQ-5D-5L instrument to the participants, the researcher asked the general practitioners (GPs) and consulting residents of internal medicine who were responsible for the participants to assist by providing information about ethics, the objectives of the research and the importance of participating. Notably, it was hypothesized that participants would be more cooperative in completing the instrument when it was introduced by the treating physician. The process of distributing the instrument took place in the outpatients' waiting rooms in the primary and secondary care settings concerned. In addition, some instruments were distributed when the participants joined the morning exercise in the T2DM community. During the data collection process, the researcher provided the material to all participants, explained the material to them, we gave them opportunity to ask related questions and assisted with filling out if needed (for example, as they had forgotten their glasses). It was not an interview but instead the participants needed further explanation on how to fill out the EQ-5D instrument.

Socio-demographic data such as gender, age, T2DM duration, occupation, level of education, and dependence on a caregiver were obtained from self-reporting. We classified the participants into two age categories based on the retirement age of Indonesian people (56 years): productive age (below 56 years) and retirement age (56 years and above). As for employment status, participants were defined as unemployed if they reported not having a job, and in active employment when they were still actively working. Those whose main responsibilities were for their family members and household chores were classified as housewives.

Data on the clinical condition such as the type of therapy, T2DM-related complications, and comorbidities were obtained from the GPs or consulting residents of internal medicine. Self-reported data from participants was used in the cases data could not be collected through GPs or residents of internal medicine. In this study, participants were defined as having comorbidities if they suffered comorbidities such as cancer, tuberculosis, gastritis, hepatitis, low back pain, urinary tract infections, and tumors, reflecting the most-reported comorbidities in the medical records of selected participants. In addition, participants with comorbidities and T2DM-related complications were considered as a separate group to be analyzed specifically.

\section{Statistical analysis}

EQ-5D index scores were calculated using the Indonesian value set [9]. Descriptive statistics were computed to compare EQ-5D index scores among different subgroups based on socio-demographic characteristics and clinical condition; both means and $95 \%$ confidence intervals (CIs) were calculated. Univariate associations between the EQ-5D index score and various participants' characteristics were subsequently tested by Chi square tests. Next, a multivariate ordinal regression analysis was conducted to explore how this score was associated with the socio-demographic characteristics and the clinical condition. This method was chosen because the EQ-5D index scores were too skewed to include as the dependent variable in the linear regression model. In addition, multinomial regression was not chosen as it cannot be conducted when there are no pre-defined cut-off values to differentiate the EQ-5D index scores into different subgroups. As a dependent variable in our ordinal regression model we used the quintiles of the EQ-5D index scores. We considered all variables that were separately included in the univariate analysis as being the independent variables in our multivariate analysis. The association was then investigated without deleting the insignificant 
independent variables. Unlike being categorical variables in the univariate analysis, the T2DM duration, fasting blood glucose (FBG), and postprandial blood glucose were entered into the model as continuous variables after comparing the corresponding goodness-of-fit of the regression models. The existence of multicollinearity in our regression model was assessed by the variance inflation factor (a value $>10$ indicates multicollinearity). Missing values on T2DM duration, FBG, and postprandial blood glucose were dealt with using multiple imputations [13]. For the multiple imputation we assumed the missing values were missing at random (MAR) and we used the multivariate imputation by chained equations (MICE) technique (also called sequential regression multiple imputation) to impute the data [14]. For simplicity and to ensure more straightforward analysis, we used only continuous variables that were included in the model (i.e., not categorical variables) to predict missing values. This means that the completed dataset of T2DM duration, FBG, and postprandial blood glucose were predicted based on the observed values of these three variables. Considering the percentage of missing measurements (about $35 \%$ for both FBG and postprandial blood glucose level), 25 imputed datasets were obtained for each measurement. The completed measures were then computed by taking the average values generated from each imputed dataset. When setting up the regression, the independent variables 'gender' and 'T2DM duration' were found to not meet the proportional odds assumption [15] when using the quintile EQ-5D index score. To relax this assumption in the regression model, the effects of these two variables were allowed to be varied across the intervals of the index score (quintile 1 and 2, quintile 2 and 3 , quintile 3 and 4 , and quintile 4 and 5). The descriptive statistics with the corresponding tests were performed using IBM SPSS Statistics for Windows, version 25 (SPSS Inc., Cambridge, MA). The ordinal regression model was built using R (R Foundation for Statistical Computing, software version 3.4.0, Vienna, Austria). A statistically significant association was defined as having a two-tailed $p$ value of $<0.05$.

\section{Results}

\section{Characteristics of the participants}

The socio-demographic characteristics and clinical condition of the participants are shown in Table 1. In total, there were 907 participants (mean age 59.3 (SD 9.7) years) included in our study, $57 \%$ were female and about $69 \%$ of female participants reported that they were housewives. Of the 359 housewives, $60 \%$ were 56 years or older and $4 \%$ had a university degree. Almost $55 \%$ of male participants were still actively working, either for the government, a company or self-employed. In this study, almost $80 \%$ of participants had a lower educational level and $66 \%$ of participants had already retired. More than $50 \%$ of the participants were accompanied by a caregiver and the majority of caregivers were comprised of spouses or children. We adjusted the socio-demographic characteristics data that were selfreported with the participants' identity cards if needed.

With regard to clinical condition, almost $50 \%$ of participants had been diagnosed with T2DM in the last five years and nearly $60 \%$ were on oral anti-diabetic (OAD) therapy. In addition, $40 \%$ of participants used insulin therapy and this was relatively more prevalent among participants in secondary care settings. In this study, $30 \%$ of participants did not report any complications and $10 \%$ of participants reported comorbidities. Notably, data on clinical condition of all participants in the secondary care setting were derived from consulting residents of internal medicine $(n=774,85 \%)$. For the participants in primary care the information on clinical condition was partly obtained via the GPs $(n=100,11 \%$ of the total population) and the remainder $(n=33,4 \%)$ was through self-reporting.

\section{EQ-5D dimensions affected by T2DM}

In total, $61 \%$ of participants reported problems (i.e. level 2 , slight problems, to level 5 , unable/extreme problems) with regard to pain/discomfort and this was found to be the highest proportion among all five dimensions (Table 1). The housewives (compared to the actively employed and unemployed) and those with lower education (compared to university degree participants) reported a higher percentage of the presence of problems on all dimensions. Participants treated in secondary care (compared to those who were treated in primary care) and participants accompanied by a caregiver (compared to participants who came alone) reported a higher percentage of problems on all dimensions except for anxiety/ depression. Retired participants reported a higher percentage of problems in mobility than those who were still productive, but this was the other way around for the anxiety/depression dimension. Participants on the island of Sulawesi reported a higher percentage of problems in pain/discomfort than those who lived on Java, but no significant differences were found in the other four dimensions.

With regard to clinical condition, the majority of participants on insulin therapy reported problems on the pain/ discomfort dimension. In addition, participants with macrovascular and microvascular complications and those with T2DM-related complications and comorbidities reported experiencing problems on the self-care and usual activity dimensions. Moreover, a higher number of T2DM-related complications seemed to be associated with more problems on the mobility and usual activities dimensions. Of the 570 participants who had a post-prandial blood glucose 
Table 1 Distribution of participants within different subgroups over reporting problems (slight to extreme problems) on the EQ-5D dimensions and mean $(95 \% \mathrm{CI}) \mathrm{EQ}-5 \mathrm{D}$ index score according to

\begin{tabular}{|c|c|c|c|c|c|c|c|}
\hline \multirow[t]{2}{*}{ Characteristics } & \multirow[t]{2}{*}{$N(\%)$} & \multicolumn{5}{|c|}{$\%$ reporting problems } & \multirow[t]{2}{*}{ EQ-5D index score $(95 \% \mathrm{CI})$} \\
\hline & & Mobility & Self-care & Usual activities & Pain/discomfort & $\begin{array}{l}\text { Anxiety/ } \\
\text { depres- } \\
\text { sion }\end{array}$ & \\
\hline Total participants & $907(100)$ & 37 & 12 & 23 & 61 & 34 & $0.77(0.75-0.79)$ \\
\hline \multicolumn{8}{|l|}{$\begin{array}{l}\text { Socio-demographic character- } \\
\text { istics }\end{array}$} \\
\hline \multicolumn{8}{|l|}{ Region } \\
\hline Java & $499(55)$ & 38 & 13 & 23 & 57 & 36 & $0.78(0.75-0.80)$ \\
\hline Sulawesi & $408(45)$ & 37 & 12 & 23 & 65 & 33 & $0.76(0.73-0.79)$ \\
\hline \multicolumn{8}{|l|}{ Sex } \\
\hline Male & $387(43)$ & 34 & 11 & 22 & 58 & 37 & $0.79(0.75-0.81)^{*}$ \\
\hline Female & $520(57)$ & 40 & 14 & 24 & 63 & 37 & $0.76(0.73-0.78)$ \\
\hline Age $(59.32 \pm 9.70)$ & $886(98)^{\#}$ & & & & & & \\
\hline Productive age ( $<56$ years) & $289(32)$ & $32 *$ & 12 & 25 & 61 & $43 * *$ & $0.77(0.73-0.80)$ \\
\hline Retirement age ( $\geq 56$ years) & $597(66)$ & 40 & 12 & 22 & 60 & 30 & $0.77(0.75-0.80)$ \\
\hline \multicolumn{8}{|l|}{ Occupation } \\
\hline Active employment & $314(35)$ & $30 * *$ & $8 * *$ & $19 * *$ & $59^{*}$ & $33 * *$ & $0.81(0.78-0.84)^{* *}$ \\
\hline Unemployed & $234(26)$ & 36 & 11 & 19 & 56 & 27 & $0.79(0.75-0.82)$ \\
\hline Housewife & 359 (39) & 45 & 17 & 30 & 66 & 41 & $0.72(0.69-0.075)$ \\
\hline \multicolumn{8}{|l|}{ Education } \\
\hline Up to senior high school & $698(77)$ & $41 * *$ & $15^{* *}$ & $27 * *$ & $65^{* *}$ & $37 * *$ & $0.74(0.72-0.76)^{* *}$ \\
\hline University degree & $209(23)$ & 24 & 4 & 12 & 48 & 27 & $0.86(0.83-0.89)$ \\
\hline \multicolumn{8}{|l|}{ Level of health facilities } \\
\hline Primary care & $133(15)$ & $20 * *$ & $3 * *$ & $8 * *$ & $40 * *$ & 41 & $0.90(0.87-0.92)^{* *}$ \\
\hline Secondary care & $774(85)$ & 40 & 14 & 26 & 64 & 33 & $0.74(0.73-0.77)$ \\
\hline \multicolumn{8}{|l|}{ Dependency on a caregiver } \\
\hline Yes & $488(54)$ & $44 * *$ & $15^{* *}$ & $27 * *$ & $64^{*}$ & 37 & $0.72(0.69-0.75)^{* *}$ \\
\hline No & $419(46)$ & 29 & 9 & 19 & 57 & 32 & $0.83(0.81-0.85)$ \\
\hline \multicolumn{8}{|l|}{ Clinical condition } \\
\hline T2DM duration ${ }^{\mathrm{a}}$ & $805(89)^{\#}$ & & & & & & \\
\hline$<5$ years & $446(49)$ & 38 & 15 & $29 * *$ & 63 & 36 & $0.76(0.74-0.79)$ \\
\hline$\geq 5$ years & $359(40)$ & 43 & 12 & 20 & 64 & 32 & $0.74(0.71-0.77)$ \\
\hline \multicolumn{8}{|l|}{ Therapy } \\
\hline $\begin{array}{l}\text { None (diet, herbal or } \\
\text { exercise) }^{\mathrm{b}}\end{array}$ & $49(5)$ & $47 * *$ & $27 * *$ & $41^{* *}$ & $59 *$ & 45 & $0.61(0.47-0.76)^{* *}$ \\
\hline $\begin{array}{l}\text { OAD (mono and combina- } \\
\text { tions) }\end{array}$ & $490(55)$ & 32 & 10 & 19 & 57 & 32 & $0.81(0.79-0.83)$ \\
\hline $\begin{array}{l}\text { Insulin (mono and combina- } \\
\text { tion with OAD) }\end{array}$ & $368(40)$ & 44 & 14 & 27 & 66 & 37 & $0.74(0.71-0.77)$ \\
\hline \multicolumn{8}{|l|}{$\begin{array}{l}\text { Types of complications and } \\
\text { comorbidities }\end{array}$} \\
\hline \multicolumn{8}{|l|}{ Complications } \\
\hline None & $269(30)$ & 33 & $8 * *$ & $14 * *$ & 57 & 33 & $0.80(0.76-0.83)^{*}$ \\
\hline Macrovascular & $290(32)$ & 38 & 11 & 23 & 59 & 33 & $0.79(0.72-0.82)$ \\
\hline Microvascular & $140(15)$ & 36 & 11 & 21 & 64 & 29 & $0.77(0.72-0.82)$ \\
\hline Macro and microvascular & $30(3)$ & 47 & 23 & 44 & 56 & 34 & $0.69(0.56-0.80)$ \\
\hline Comorbidities $^{\mathrm{c}}$ & $86(10)$ & 36 & 20 & 36 & 69 & 44 & $0.71(0.65-0.78)$ \\
\hline $\begin{array}{l}\text { Comorbidities + T2DM com- } \\
\text { plications }\end{array}$ & $92(10)$ & 49 & 22 & 36 & 67 & 42 & $0.70(0.63-0.76)$ \\
\hline
\end{tabular}

socio-demographic characteristics and clinical condition in Indonesian T2DM outpatients using the Indonesian EQ-5D tariff 
Table 1 (continued)

\begin{tabular}{|c|c|c|c|c|c|c|c|}
\hline \multirow[t]{2}{*}{ Characteristics } & \multirow[t]{2}{*}{$N(\%)$} & \multicolumn{5}{|c|}{$\%$ reporting problems } & \multirow[t]{2}{*}{ EQ-5D index score $(95 \% \mathrm{CI})$} \\
\hline & & Mobility & Self-care & Usual activities & Pain/discomfort & $\begin{array}{l}\text { Anxiety/ } \\
\text { depres- } \\
\text { sion }\end{array}$ & \\
\hline \multicolumn{8}{|l|}{$\begin{array}{l}\text { Number of T2DM complica- } \\
\text { tions }\end{array}$} \\
\hline None & $269(30)$ & $33 *$ & $8^{*}$ & $14 * *$ & 57 & 33 & $0.80(0.76-0.83)$ \\
\hline $1 \mathrm{~T} 2 \mathrm{DM}$ complication & $341(37)$ & 35 & 11 & 22 & 61 & 31 & $0.79(0.76-0.81)$ \\
\hline $\begin{array}{l}2 \text { or more T2DM complica- } \\
\text { tions }\end{array}$ & $119(13)$ & 48 & 12 & 29 & 58 & 37 & $0.74(0.69-0.80)$ \\
\hline \multicolumn{8}{|l|}{ Blood glucose level } \\
\hline Random blood glucose & $147\left(16^{\#}\right.$ & & & & & & \\
\hline$\leq 200 \mathrm{mg} / \mathrm{dl}$ & $73(8)$ & 23 & 9 & 20 & 37 & 22 & $0.70(0.62-0.76)$ \\
\hline$>200 \mathrm{mg} / \mathrm{dl}$ & $74(8)$ & 26 & 12 & 23 & 36 & 27 & $0.63(0.54-0.71)$ \\
\hline Fasting blood glucose & $685(76)^{\#}$ & & & & & & \\
\hline$\leq 126 \mathrm{mg} / \mathrm{dl}$ & $265(30)$ & 15 & 4 & 8 & 23 & $10 *$ & $0.79(0.75-0.82)$ \\
\hline$>126 \mathrm{mg} / \mathrm{dl}$ & $420(46)$ & 24 & 9 & 15 & 40 & 21 & $0.75(0.72-0.78)$ \\
\hline Postprandial blood glucose & $570(63)^{\#}$ & & & & & & \\
\hline$\leq 200 \mathrm{mg} / \mathrm{dl}$ & $309(34)$ & $18 *$ & $4^{*}$ & $10 *$ & 32 & 15 & $0.81(0.78-0.84)^{*}$ \\
\hline$>200 \mathrm{mg} / \mathrm{dl}$ & $261(29)$ & 19 & 6 & 12 & 29 & 15 & $0.76(0.73-0.79)$ \\
\hline
\end{tabular}

${ }^{\#}$ Reporting rate: $p$ value: Chi square; $* p$ value $<0.05 ; * * p$ value $<0.01$

${ }^{\mathrm{a}} 11 \%$ of respondents did not know the duration of their T2DM

${ }^{b}$ Five participants reported that the reason for not taking metformin was the occurrence of side effects such as dizziness and nausea. Besides that, five participants with normal blood sugar levels but abnormal blood pressure levels requested that they only be given antihypertensive medication because they felt scared if they had to take more than three pills at a time

${ }^{c}$ Comorbidities were defined as diseases other than T2DM complications, such as cancer, tuberculosis, gastritis, low back pain, urinary tract infections, and tumors

test, participants with blood glucose of $>200 \mathrm{mg} / \mathrm{dl}$ also reported problems on the mobility, self-care, and usual activity dimensions.

\section{Univariate association between EQ-5D index scores and the participant characteristics}

The average EQ-5D index score in Indonesian T2DM outpatients was 0.77 (95\% CI 0.75-0.79). The score of 0.77 was derived from the calculation of total EQ-5D index score of the study respondents with the Indonesian general population TTO value set [9]. Male participants had a higher EQ-5D index score compared to female participants (Table 1). Based on occupation, housewives had the lowest EQ-5D index score compared to actively employed and unemployed participants. Participants treated in secondary care and those with a lower level of education had a lower EQ-5D index score compared to those in primary care and with higher education, respectively. Furthermore, we also found that participants who were accompanied by a caregiver during a visit to a health facility indicated lower EQ-5D index scores compared with participants who came alone (Fig. 1).
With regard to clinical condition, the EQ-5D index scores in participants with OADs (mono or combination therapy) were higher than those on insulin therapy or those not undergoing therapy. Furthermore, participants with T2DM-related complications or comorbidities reported lower EQ-5D index scores than those without complications or comorbidities. In addition, participants with controlled blood sugar reported a higher EQ-5D index score compared to those who had uncontrolled blood sugar.

\section{Multivariate association between EQ-5D index scores and the participant characteristics}

Table 2 presents the results of the multivariate ordinal regression model. No multicollinearity was detected in the model. Several characteristics of the participants were shown to significantly influence the EQ-5D index score, mostly in line with the results of the univariate analysis presented above. Participants in secondary care had a lower EQ-5D index score compared to those in primary care. Again, higher education contributed to a significantly better HRQoL for the participants in our study. A caregiver 


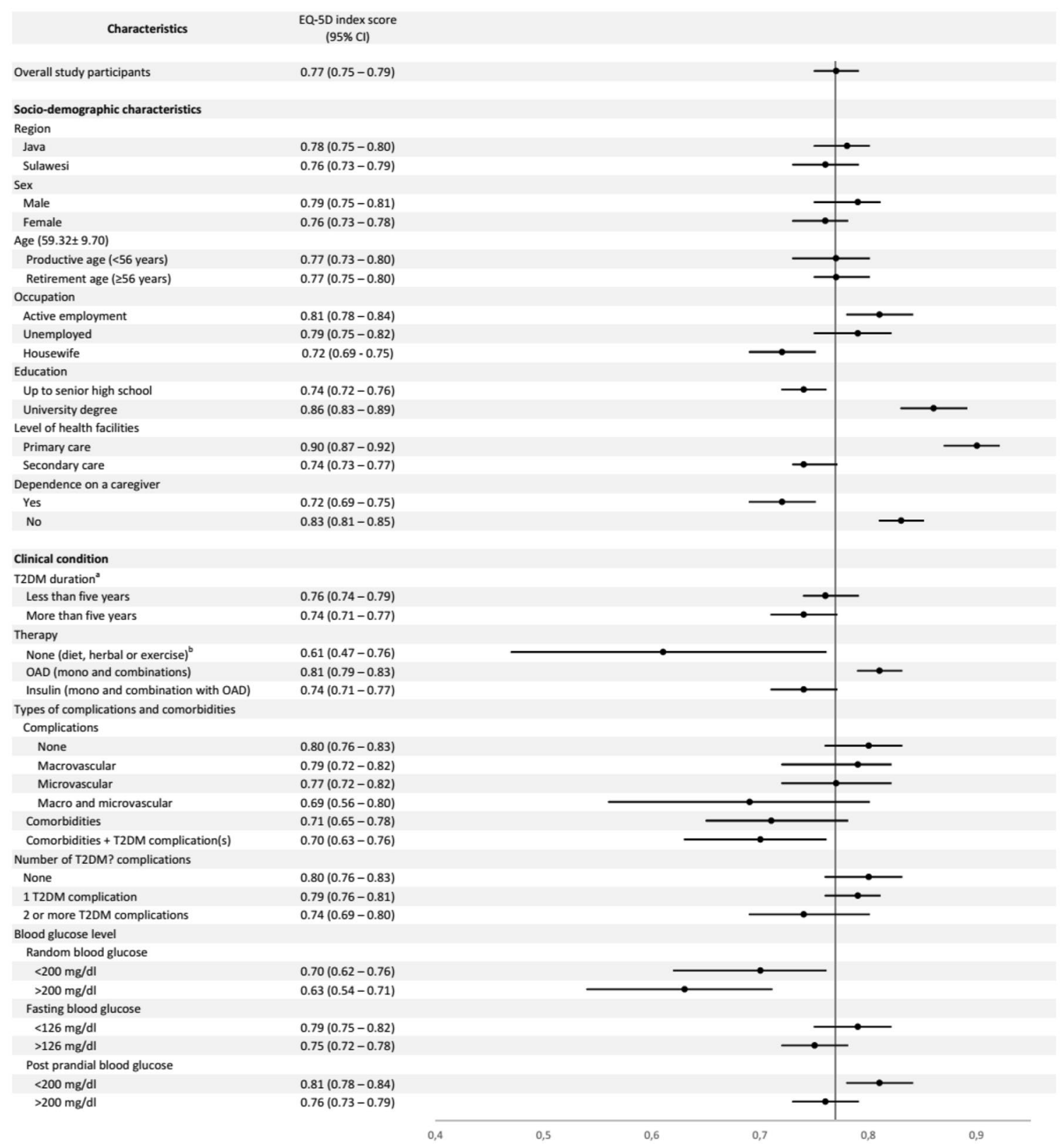

Fig. 1 Mean (95\% CI) EQ-5D index score according to socio-demographic characteristics and clinical condition in Indonesian T2DM outpatients using the Indonesian EQ-5D-5L tariff

accompanying the participant was shown to be negatively associated with HRQoL. In addition, housewives had a lower EQ-5D index score compared to active employees. The variables with regard to clinical condition were all shown to not significantly influence the index score except for treatment using monotherapy and combinations of OADs. Not surprisingly, participants having treatment using OADs had a two-fold EQ-5D index score compared to those who were not being treated using OADs.

\section{Discussion}

This is the first population-based study that reported EQ-5D index scores based on socio-demographic characteristics and clinical condition in Indonesian T2DM outpatients. We found five factors that were significantly associated with lower EQ-5D index scores in our multivariate model: treatment in secondary care, lower educational level, dependency on caregivers, occupation as a 
Table 2 Association between socio-demographic characteristics, clinical condition and EQ-5D index scores using a multivariate ordinal regression model

\begin{tabular}{|c|c|c|}
\hline Variables & Coefficient $(95 \% \mathrm{CI})$ & $p$ value \\
\hline \multicolumn{3}{|l|}{ Socio-demographic characteristics } \\
\hline From Sulawesi (vs from Java) & $0.88(0.68-1.14)$ & 0.344 \\
\hline Secondary care (vs primary care) & $0.32(0.23-0.48)$ & $<0.001$ \\
\hline Age & $0.79(0.60-1.05)$ & 0.113 \\
\hline University degree (vs high school) & $1.83(1.33-2.53)$ & $<0.001$ \\
\hline With caregiver (vs no caregiver) & $0.65(0.51-0.84)$ & $<0.001$ \\
\hline Retired (vs active employee) & $0.86(0.61-1.21)$ & 0.382 \\
\hline Housewife (vs active employee) & $0.62(0.42-0.91)$ & 0.014 \\
\hline \multirow[t]{3}{*}{ Female (vs male) } & $0.96(0.62-1.50)$ [quintile 1 and 2] & 0.886 \\
\hline & $0.96(0.66-1.42)$ [quintile 2 and 3] & 0.858 \\
\hline & $1.44(0.98-2.11)$ [quintile 3 to 5 ] & 0.064 \\
\hline \multicolumn{3}{|c|}{$\begin{array}{l}\text { Clinical condition (vs no complications/comor- } \\
\text { bidities) }\end{array}$} \\
\hline One complication & $1.09(0.80-1.48)$ & 0.585 \\
\hline Two or more complications & $0.74(0.49-1.11)$ & 0.142 \\
\hline Comorbidities & $0.73(0.46-1.17)$ & 0.196 \\
\hline Complications and comorbidities & $0.71(0.45-1.12)$ & 0.137 \\
\hline Oral antidiabetic (vs none) & $2.18(1.22-3.89)$ & 0.008 \\
\hline Insulin (vs none) & $1.55(0.86-2.82)$ & 0.147 \\
\hline Fasting blood glucose $\mathrm{a}^{\mathrm{a}}(n=685)^{\mathrm{b}}$ & $0.99(0.99-1.00)$ & 0.397 \\
\hline Postprandial blood glucose ${ }^{\mathrm{a}}(n=570)^{\mathrm{b}}$ & $0.99(0.99-1.00)$ & 0.074 \\
\hline \multirow[t]{3}{*}{ T2DM duration } & $1.00(0.98-1.03)$ [quintile 1 and 2] & 730 \\
\hline & $0.99(0.97-1.01)$ [quintile 2 and 3] & 0.505 \\
\hline & $0.98(0.96-1.01)$ [quintile 3 to 5 ] & 0.132 \\
\hline
\end{tabular}

housewife and not undergoing T2DM therapy. The mean EQ-5D index score in Indonesian T2DM outpatients in this study was estimated at 0.77 (95\% CI 0.75-0.79).

The mean EQ-5D index score in Indonesian T2DM outpatients in our study, 0.77, is lower than that reported for the Indonesian general population at 0.91 [9]. Furthermore, a previous study by Perwitasari et al. in Indonesian T2DM outpatients $(n=86)$ reported that the EQ-5D index score was 0.75 (SD 0.22) [16]. Related to clinical condition, Perwitasari et al. also found that T2DM complications were indeed aligned with decreases in EQ-5D index scores. Notably, despite the similarities, Perwitasari et al. used different methods to measure and analyze the data, i.e., the EQ-5D-3L instrument and the Thailand TTO value set, which complicates comparison [16]. Our estimate is in line with what was previously found in a meta-analysis on EQ-5D in mostly T2DM patients at 0.76 (95\% CI 0.75-0.77) [17], despite that the meta-analysis comprised populations from various backgrounds, including high, middle and low-income countries as well as various stages of disease in DM, hampering a straightforward comparison with our study.
Concerning self-reported health, the percentage of T2DM outpatients in our study that reported any problems is higher than reported for the general population in four out of five dimensions: mobility (37\% and $8 \%$, respectively), self-care (12\% and 2\%), usual activities (23\% and 11\%), and pain/ discomfort (61\% and 40\%) [9]. Notably, for the anxiety/ depression dimension, we found $34 \%$ compared to $35 \%$ in the general population [9]. This shows that T2DM has an adverse impact on HRQoL. Our finding that the EQ-5D index score in female participants is lower than in males seems to be consistent with previous studies in similar participants [18-21]. A possible explanation for this might be that female participants are more likely to report anxiety/ depression problems as they have been reported to have more diabetes-related worries, less satisfied with treatment regimens, and less ability to cope with their disease [22, 23]. However, when we controlled for socio-demographic characteristics and clinical condition in the multivariate ordinal regression model, the difference between males and females was no longer significant. This may be due to the fact that $69 \%$ of the females were housewives (with $96 \%$ with lower 
education) and being a housewife was already significantly associated with a lower EQ-5D index score. It could be argued that for Indonesian housewives who have the responsibility for taking care of the family members and household chores, having a chronic illness such as T2DM represents an extra burden in fulfilling these tasks. Percentages in this subgroup reporting problems on all of the EQ-5D dimensions indeed confirmed this being significantly higher than in the other subgroups of actively employed and unemployed.

Some publications on HRQoL in Indonesian T2DM outpatients exist, mainly conducted on the island of Java $[16,24]$. In this study, we focused on socio-demographic characteristics and clinical condition of Indonesian T2DM outpatients in two major islands, namely Java and Sulawesi. To get a better description on the characteristics of T2DM participants, we compared ours with two previous studies $[16,24]$. These two studies were of particular interest as one used a previous version of the same instrument, i.e., EQ-5D [16] and the other focused on socio-demographic characteristics and HRQoL in Indonesian T2DM outpatients using the diabetes quality of life clinical trial questionnaire (DQLCTQ) $(n=83)$ [24]. Both of these studies reported that the percentage of female participants was higher than male participants. In addition to that, most participants in both studies were aged 55 years or older. Notably, some differences between our study and the other two studies concerned the percentages of participants with a university background as compared to only a high school background. A detailed description of this issue can be found in the "Appendix".

Our findings showed that higher educational levels lead to higher HRQoL, which was similar to findings from studies in other countries, such as in Korea, Japan and Iran [18-20]. It could be argued that participants with a higher level of education might have a better understanding of the T2DM therapy and the impact of T2DM-related complications, and therefore, have a more conscientious attitude towards their therapy [21].

Participants who were treated in secondary care were found to have lower HRQoL than those who were treated in primary care. This seems reasonable since worse cases are generally referred from the primary to secondary healthcare facilities with higher severity of T2DM. Similar explanations could be given for findings on lower index scores of participants needing help from their caregivers compared to those who did not need such help: a worse condition likely involves more need for help as well as being associated with a lower HRQoL.

During the data collection process, approximately 550 participants were assisted with filling out the EQ-5D instrument, amongst which approximately $3 / 4$ s were elderly and the rest were participants in the productive age with an education level only up to senior high school. The researcher or research assistant sat next to them, explaining and/or assisting them to read and comprehend each item. Some reasons for this assistance were that they forgot to bring their glasses, were too tired because of the bureaucracy in the hospital, or needed explanation concerning the difference between levels of the EQ-5D instrument $[25,26]$. We examined whether our assistance filling out the instrument influenced our results. For that purpose, we calculated the frequencies of problems reported based on those participants who were assisted versus those not assisted and the results were similar (data not shown).

Some limitations of this study have to be acknowledged. First, we collected data only on two major islands of Indonesia, namely Java and Sulawesi. Representativeness of the study sample for the whole of Indonesia can obviously not be straightforwardly claimed. Yet, given our choice for the most densely populated central island (Java) and a more remote area (Sulawesi), we did include a spectrum in our sample covering some ethnic variety and some representativeness may definitely exist. Second, there were 21 participants that had missing information on their date of birth for privacy reasons. As these 21 participants only constitute a minor part (2\%) of the total sample, and also because age was not found to be associated with EQ-5D index scores it is unlikely this has had a profound influence on our results. Lastly, the multiple imputation approach we conducted only used the evidence from the available continuous variables to predict the missing information. This did not take into account the potential influence of the categorical variables that were included in the multivariable model. We would, however, not expect this limitation to relevantly impact our results. In addition, a "rule of thumb" to use a number of imputations equal to the percentage of missing data was used as proposed by White et al. [27]. This would imply 35 imputed datasets instead of 25 in this study. However, increasing the number of imputed datasets had hardly any impact on the results presented in this study after performing a sensitivity analysis (results not shown).

\section{Conclusion}

This study provides estimates of EQ-5D index scores that can be used in health economic evaluations. Five factors were found in our multivariate model to be significantly associated with lower EQ-5D index scores: treatment in secondary care, lower educational level, dependency on caregivers, occupation as a housewife and not undergoing T2DM therapy. Housewives are prone to experiencing T2DM-related pain/discomfort and anxiety/depression, therefore, specific approaches to reduce these problems should be aimed specifically to this group of patients. Potential approaches could involve disease-specific counselors (health literacy partners) who provide routine 
monitoring of T2DM therapy as well as improved health promotion among T2DM communities.

\section{Recommendation}

We recommend the development of a specific approach targeting housewives living with T2DM and T2DM patients with lower levels of education. Given their decrease in HRQoL compared to the average T2DM outpatients in this study, there is an urgent need for improvement. Such health promotions could be integrated with existing health programmes, such as Prolanis BPJS/Badan Penyelenggara Jaminan Sosial, a targeted diabetes program run by the social security administrative agency.

Acknowledgements We acknowledge the help of all the participants, the LPDP scholarship (for the first author) from the Ministry of Finance of the Republic of Indonesia, Badan Penyelenggara Jaminan Sosial (BPJS), Prolanis BPJS Surabaya, Persadia Surabaya and Jawa Timur, the Governor of Central Sulawesi and the Regent of Banggai Laut (Drs. H. Wenny Bukamo), Prof. Dr. dr. Muhamad Bambang Purwanto, M.A, dr. Supriyanto Kartodarso, Sp.PD, KEMD FINASIM, dr. Eva Niamuzisilawati, Sp.PD, M.Kes, dr. Makiyatul Munawaroh, Sp.PD, dr. Ikrimah Nisa Utami, Selly Ristya Ningsih, M. Ikhsan Jufri, Muh. Ramlan Budi Kusuma, Friyanti Zaman, Suryadin, Nurhida Martya Yupitasari, Dianita Ayu Ningrum, Ardiansyah Permana, Irfa Ismayanti, Laili Nur Ammajida, Amri Muarif and M. Rifqi Rokhman, M.Sc., Apt.

Author contributions BA, FDP, ADIvA, QC, PK, and MJP were involved in the conceptualization and the design of the study. BA and DAP carried out the data collection. BA and QC conducted the analyses, and ADIvA, PK, and MJP were the main consultants in the data analyses. All the authors commented on the final analysis. BA, ADIvA and LI drafted the manuscript, and all the authors revised it. All the authors read and approved the final manuscript.

Funding The research was supported by a Grant from Beasiswa Pendidikan Indonesia (BPI)/ LPDP (the Indonesian Endowment Fund for Education, Ministry of Finance of Republic of Indonesia) with contract number 20130821080334 and the University of Groningen in the Netherlands (project code 134502).

\section{Compliance with ethical standards}

Competing interests MJP reports grants and honoraria from various pharmaceutical companies, including those developing, producing and marketing diabetes drugs. However, all Grants and honoraria were fully unrelated to this specific study. The other authors declare that they have no competing interests related to this specific study and topic.

Ethical approval All procedures performed in studies involving human participants were in accordance with the ethical standards of the institutional and/or national research committee and with the 1964 Helsinki Declaration and its later amendments or comparable ethical standards.

Informed consent Informed consent was obtained from all individual participants included in the study.
OpenAccess This article is distributed under the terms of the Creative Commons Attribution 4.0 International License (http://creativeco mmons.org/licenses/by/4.0/), which permits unrestricted use, distribution, and reproduction in any medium, provided you give appropriate credit to the original author(s) and the source, provide a link to the Creative Commons license, and indicate if changes were made.

\section{Appendix: Comparing key demographic characteristics of our study participants with two previously published articles [16, 24]}

\begin{tabular}{|c|c|c|c|}
\hline \multirow[t]{2}{*}{ Characteristics } & \multicolumn{3}{|l|}{$N(\%)$} \\
\hline & $\begin{array}{l}\text { Arifin et al. } \\
\text { (The present } \\
\text { study) }\end{array}$ & $\begin{array}{l}\text { Perwitasari } \\
\text { et al. [16] }\end{array}$ & $\begin{array}{l}\text { Restinia et al. } \\
\text { [24] }\end{array}$ \\
\hline HRQoL instrument & $\begin{array}{c}\text { EQ-5D-5L } \\
\text { (Indonesia } \\
\text { value set) }\end{array}$ & $\begin{array}{l}\text { EQ-5D-3L } \\
\text { (Thailand } \\
\text { value set) }\end{array}$ & DQLCTQ \\
\hline $\begin{array}{l}\text { EQ-5D index score } \\
(95 \% \mathrm{CI})\end{array}$ & $\begin{array}{c}0.77(95 \% \mathrm{CI} \\
0.75-0.79)\end{array}$ & $\begin{array}{c}0.75(\mathrm{SD} \\
0.22)\end{array}$ & NA \\
\hline $\begin{array}{l}\text { Overall study par- } \\
\text { ticipants }\end{array}$ & $907(100)$ & $86(100)$ & $83(100)$ \\
\hline \multicolumn{4}{|l|}{$\begin{array}{l}\text { Socio-demographic } \\
\text { characteristics }\end{array}$} \\
\hline $\begin{array}{l}\text { Number of study } \\
\text { sites }\end{array}$ & 8 & 1 & 1 \\
\hline Location & $\begin{array}{l}\text { Java and } \\
\text { Sulawesi }\end{array}$ & $\begin{array}{l}\text { Singkawang, } \\
\text { West Kali- } \\
\text { mantan }\end{array}$ & Jakarta \\
\hline \multicolumn{4}{|l|}{ Sex } \\
\hline Male & 387 (43) & $37(43)$ & $31(37)$ \\
\hline Female & $520(57)$ & $49(57)$ & $52(63)$ \\
\hline Mean age & 59.3 (SD 9.7) & $58.2(\mathrm{SD} 7.8)$ & $>50$ years \\
\hline Age & $886(98)$ & $86(100)$ & $83(100)$ \\
\hline $\begin{array}{l}\text { Productive age } \\
(<56 \text { years })\end{array}$ & $289(32)$ & NR & $3(4)$ \\
\hline $\begin{array}{l}\text { Retirement age } \\
\quad(\geq 56 \text { years })\end{array}$ & $597(66)$ & NR & $80(96)$ \\
\hline \multicolumn{4}{|l|}{ Occupation } \\
\hline $\begin{array}{l}\text { Active employ- } \\
\text { ment }\end{array}$ & $314(35)$ & $53(62)$ & $3(4)$ \\
\hline Unemployed & $234(26)$ & $33(38)$ & $80(96)$ \\
\hline Housewife & 359 (39) & NR & NR \\
\hline \multicolumn{4}{|l|}{ Education } \\
\hline $\begin{array}{l}\text { Up to senior high } \\
\text { school }\end{array}$ & $698(77)$ & $31(36)$ & $35(42)$ \\
\hline University degree & $209(23)$ & $55(64)$ & $48(58)$ \\
\hline \multicolumn{4}{|l|}{$\begin{array}{l}\text { Level of health } \\
\text { facilities }\end{array}$} \\
\hline Primary care & $133(15)$ & $0(0)$ & $0(0)$ \\
\hline Secondary care & $774(85)$ & $86(100)$ & $83(100)$ \\
\hline $\begin{array}{l}\text { Dependence on a } \\
\text { caregiver }\end{array}$ & & & \\
\hline
\end{tabular}




\begin{tabular}{|c|c|c|c|}
\hline \multirow[t]{2}{*}{ Characteristics } & \multicolumn{3}{|l|}{$N(\%)$} \\
\hline & $\begin{array}{l}\text { Arifin et al. } \\
\text { (The present } \\
\text { study) }\end{array}$ & $\begin{array}{l}\text { Perwitasari } \\
\text { et al. [16] }\end{array}$ & $\begin{array}{l}\text { Restinia et al. } \\
\text { [24] }\end{array}$ \\
\hline Yes & $488(54)$ & NR & NR \\
\hline No & $419(46)$ & NR & NR \\
\hline \multirow[t]{2}{*}{$\begin{array}{l}\text { Monthly income } \\
\text { (1 USD\$ = IDR } \\
14.835)\end{array}$} & NR & $\begin{array}{l}<2.2 \text { million } \\
(\$ 148): 30 \\
(35)\end{array}$ & $\begin{array}{l}<3 \text { million } \\
\quad(\$ 202): 47 \\
(57)\end{array}$ \\
\hline & NR & $\begin{array}{l}>2.2 \text { million: } \\
56(65)\end{array}$ & $\begin{array}{l}>3 \text { million: } 36 \\
(43)\end{array}$ \\
\hline $\begin{array}{l}\text { Family history of } \\
\text { T2DM (yes) }\end{array}$ & NR & $53(62)$ & NR \\
\hline $\begin{array}{l}\text { Marital status } \\
\text { (married) }\end{array}$ & NR & $76(88)$ & NR \\
\hline \multicolumn{4}{|l|}{ Clinical condition } \\
\hline T2DM duration ${ }^{\mathrm{a}}$ & 805 (89) & $\begin{array}{l}\text { Mean } 6.7 \\
\quad(\text { SD } 4.9)\end{array}$ & NR \\
\hline Less than 5 years & $446(49)$ & NR & $14(17)$ \\
\hline $\begin{array}{l}\text { More than } \\
5 \text { years }\end{array}$ & $359(40)$ & NR & $69(83)$ \\
\hline \multicolumn{4}{|l|}{ Therapy } \\
\hline $\begin{array}{l}\text { None (diet, herbal } \\
\text { or exercise) }\end{array}$ & $49(5)$ & $0(0)$ & NR \\
\hline $\begin{array}{l}\text { OAD (mono and } \\
\text { combinations) }\end{array}$ & $490(55)$ & $78(91)$ & NR \\
\hline \multirow{2}{*}{$\begin{array}{l}\text { Insulin (mono } \\
\text { and combina- } \\
\text { tion with OAD) }\end{array}$} & $368(40)$ & $8(9)$ & NR \\
\hline & & & NR \\
\hline \multicolumn{4}{|l|}{$\begin{array}{l}\text { Types of com- } \\
\text { plications and } \\
\text { comorbidities }\end{array}$} \\
\hline \multicolumn{4}{|l|}{ Complications } \\
\hline None & $269(30)$ & $0(0)$ & NR \\
\hline Macrovascular & $290(32)$ & $49(57)$ & NR \\
\hline Microvascular & $140(15)$ & $12(14)$ & NR \\
\hline $\begin{array}{l}\text { Macro and } \\
\text { microvascular }\end{array}$ & $30(3)$ & $25(29)$ & NR \\
\hline Comorbidities & $86(10)$ & NR & NR \\
\hline $\begin{array}{l}\text { Comorbidi- } \\
\text { ties + T2DM } \\
\text { complication(s) }\end{array}$ & $92(10)$ & NR & NR \\
\hline \multicolumn{4}{|l|}{$\begin{array}{l}\text { Number of T2DM } \\
\text { complications }\end{array}$} \\
\hline None & $269(30)$ & NR & NR \\
\hline $\begin{array}{l}1 \text { T2DM compli- } \\
\text { cation }\end{array}$ & $341(37)$ & NR & NR \\
\hline $\begin{array}{l}2 \text { or more } \mathrm{T} 2 \mathrm{DM} \\
\text { complications }\end{array}$ & $119(13)$ & NR & NR \\
\hline \multicolumn{4}{|l|}{ Blood glucose level } \\
\hline $\begin{array}{l}\text { Random blood } \\
\text { glucose }^{\mathrm{a}}\end{array}$ & 147 (16) & NR & NR \\
\hline$<200 \mathrm{mg} / \mathrm{dl}$ & $73(8)$ & & NR \\
\hline$>200 \mathrm{mg} / \mathrm{dl}$ & $74(8)$ & & NR \\
\hline
\end{tabular}

\begin{tabular}{|c|c|c|c|}
\hline \multirow[t]{2}{*}{ Characteristics } & \multicolumn{3}{|l|}{$N(\%)$} \\
\hline & $\begin{array}{l}\text { Arifin et al. } \\
\text { (The present } \\
\text { study) }\end{array}$ & $\begin{array}{l}\text { Perwitasari } \\
\text { et al. [16] }\end{array}$ & $\begin{array}{l}\text { Restinia et al. } \\
{[24]}\end{array}$ \\
\hline $\begin{array}{l}\text { Fasting blood } \\
\text { glucose }^{\mathrm{a}}\end{array}$ & $685(76)$ & $\begin{array}{r}\text { Mean 159 } \\
\text { (SD 70) }\end{array}$ & NR \\
\hline$<126 \mathrm{mg} / \mathrm{dl}$ & $265(30)$ & & NR \\
\hline$>126 \mathrm{mg} / \mathrm{dl}$ & $420(46)$ & & NR \\
\hline $\begin{array}{l}\text { Post prandial } \\
\text { blood glucose }^{\mathrm{a}}\end{array}$ & $570(63)$ & $\begin{array}{r}\text { Mean 245 } \\
\quad(\text { SD 90) }\end{array}$ & NR \\
\hline$<200 \mathrm{mg} / \mathrm{dl}$ & 309 (34) & & NR \\
\hline$>200 \mathrm{mg} / \mathrm{dl}$ & $261(29)$ & & NR \\
\hline
\end{tabular}

$N R$ not reported, $N A$ not available, $D Q L C T Q$ Diabetes Quality of Life Clinical Trial Questionnaire

${ }^{\mathrm{a}}$ Reporting rate

\section{References}

1. WHO Diabetes. (2015). World Health Organisation. Retrieved April 6, 2015, from http://www.who.int/mediacentre/factsheets/ fs $312 / e n /$.

2. CDC. (2015). Diabetes prevention and control program FY 2015 appropriations fact sheet centers for disease control and prevention. Atlanta: CDC. http://c.ymcdn.com/sites/www.chronicdis ease.org/resource/resmgr/2015_Appropriations_Fact_Sheets/ DH3282015_Diabetes_Approp_Sh.pdf.

3. PUSDATIN. (2014). Situasi dan analisis diabetes. Jakarta: PUSDATIN. http://www.depkes.go.id/resources/download/pusdatin/ infodatin/infodatin-diabetes.pdf.

4. IDF. (2017). IDF diabetes atlas (8th edn., pp. 1-150). Brussels: International Diabetes Federation.

5. IDF. (2011). IDF diabetes atlas (5th edn.). Brussels: International Diabetes Federation.

6. Soewondo, P., Ferrario, A., \& Tahapary, D. L. (2013). Challenges in diabetes management in Indonesia: A literature review. Global Health, 9, 63-80. http://search.proquest.com.virtual.anu.edu. $\mathrm{au} /$ docview/1491517774/fulltextPDF/E53ABED4535C.4A40P $\mathrm{Q} / 137$ ? accountid $=8330$.

7. McCall, C. (2016). Country in focus: Indonesia struggles to pay for the increase in diabetes. The Lancet Diabetes \& Endocrinology, 4, 653-654. https://doi.org/10.1016/S2213-8587(16)30160 $-7$.

8. Trikkalinou, A., Papazafiropoulou, A. K., \& Melidonis, A. (2017). Type 2 diabetes and quality of life. World Journal of Diabetes, 8 , 120-171.

9. Purba, F. D., Hunfeld, J. A. M., Iskandarsyah, A., Fitriana, T. S., Sadarjoen, S. S., Ramos-Goñi, J. M., et al. (2017). The Indonesian EQ-5D-5L Value Set. Pharmacoeconomics. https://doi. org/10.1007/s40273-017-0538-9.

10. BPS. (2015). Statistik Indonesia (Statistical year book of Indonesia).Sub-directorate_of_Statistica_Compilation. Jakarta: Badan Pusat Statistik (BPS Statistic Indonesia).

11. EUROQoL-Group. EQ-5D-5L. Eur. Qual. Life. 2016. Retrieved May 23, 2017, from http://www.euroqol.org/fileadmin/user_uploa d/Documenten/PDF/Folders_Flyers/EQ-5D-5L_UserGuide_2015. pdf.

12. Krabbe, P. F. M. (2016). The measurement of health and health ttatus: Concepts, methods, and applications from a multidisclipinary perpective. San Diego: Elsevier/Academic Press. 
13. Rubin, D. B. (1996). Multiple imputation after $18+$ years. Journal of the American Statistical Association, 91, 473-489.

14. Azur, M. J., Stuart, E. A., Frangakis, C., \& Leaf, P. J. (2011). Multiple imputation by chained equations: What is it and how does it work? International Journal of Methods in Psychiatric Research, 20, 40-49.

15. Brant, R. (1990). Assessing proportionality in the proportional odds model for ordinal logistic regression. Biometrics, 46, 1171-1178.

16. Perwitasari, D. A., Urbayatun, S., Faridah, I. N., \& Masyithah, N. (2017) Relationship of therapeutic outcome with quality of life on type 2 diabetes mellitus patients in Abdul Azis Singkawang hospital. IOP Conference Series: Materials Science and Engineering, $259,1-7$.

17. Lung, T. W. C., Hayes, A. J., Hayen, A., Farmer, A., \& Clarke, P. M. (2011). A meta-analysis of health state valuations for people with diabetes: Explaining the variation across methods and implications for economic evaluation. Quality of Life Research, 20, 1669-1678.

18. Sakamaki, H., Ikeda, S., Ikegami, N., Uchigata, Y., Iwamoto, Y., Origasa, H., et al. (2006). Measurement of HRQL using EQ-5D in patients with type 2 diabetes mellitus in Japan. Value Health International Society for Pharmacoeconomics and Outcomes Research (ISPOR), 9, 47-53. https://doi.org/10.111 1/j.1524-4733.2006.00080.x.

19. Lee, W. J., Song, K.-H., Noh, J. H., Choi, Y. J., \& Jo, M.-W. (2012). Health-related quality of life using the EuroQol 5D questionnaire in Korean patients with type 2 diabetes. Journal of Korean Medical Science, 27, 255-260.

20. Javanbakht, M., Abolhasani, F., Mashayekhi, A., Baradaran, H. R., \& Jahangiri noudeh, Y. (2012). Health related quality of life in patients with type 2 diabetes mellitus in Iran: A national survey. PLOS ONE, 7, 1-9.
21. Lu, Y., Wang, N., Chen, Y., Nie, X., Li, Q., Han, B., et al. (2017) Health-related quality of life in type-2 diabetes patients: A crosssectional study in East China. BMC Endocrine Disorders, 17, 1-7. https://doi.org/10.1186/s12902-017-0187-1.

22. Undén, A.-L., Elofsson, S., Andréasson, A., Hillered, E., Eriksson, I., \& Brismar, K. (2008). Gender differences in self-rated health, quality of life, quality of care, and metabolic control in patients with diabetes. Gender Medicine, 5, 162-180.

23. Rubin, R. R., \& Peyrot, M. (1999). Quality of life and diabetes. Diabetes/Metabolism Research and Reviews, 15, 205-218.

24. Restinia, M., Anggriani, Y., Meryta, A., \& Kusumaeni, T. (2016). Sociodemographic characteristic and health related quality of life in outpatients of type 2 diabetes mellitus under JKN. Jurnal Sains Farmasi \& Klinis, 3, 91-98.

25. Arifin, B., Perwitasari, D. A., Cao, Q., Atthobari, J., Krabbe, P. F., \& Postma, M. J. (2017). Translation, revision and validation of the diabetes distress scale for Indonesian type 2 diabetic outpatients with various types of complications. Value in Health Regional Issues, 12C, 63-73.

26. Arifin, B., van Asselt, A. D. I., Cao, Q., Idrus, L., At-Thobati, J., Krabbe, P. F., et al. (2016). From visualization to understanding: A tool to enhance valid completion of EQ-5D-5L by Indonesian T2DM outpatients (poster presentation). Berlin: EuroQoL Group.

27. White, I. R., Royston, P., \& Wood, A. M. (2011). Multiple imputation using chained equations: Issues and guidance for practice. Statistics in Medicine, 30, 377-399.

Publisher's Note Springer Nature remains neutral with regard to jurisdictional claims in published maps and institutional affiliations. 